\title{
Improved method for the determination of triacylglycerols in olive oils by high performance liquid chromatography
}

\author{
By W. Moreda*, M.C. Pérez-Camino and A. Cert
}

\author{
Instituto de la Grasa (C.S.I.C.), Avda. Padre García Tejero, 4, E-41012, Sevilla, España \\ E-mail:wmoreda@ig.csic.es
}

\section{RESUMEN}

\begin{abstract}
Método mejorado para la determinación de triglicéridos en aceites de oliva mediante cromatografía líquida de alta eficacia.
\end{abstract}

El análisis de triacilgliceroles tiene gran importancia como herramienta en el control de calidad y en la determinación del origen de los aceites de oliva. Nuevas mejoras en el análisis de triacilgliceroles en aceite de oliva mediante cromatografía líquida de alta eficacia se han desarrollado para mejorar la separación entre las parejas críticas LLL/OLLn y OLL/OOLn usadas en la detección de aceites de semilla en aceite de oliva. Eluciones con acetona/acetonitrilo $(55: 45)$ usando gradiente de temperatura y elución con propionitrilo en condiciones isotérmicas han sido investigadas en comparación con el método oficial de la Unión Europea. La mejor resolución se consiguió usando propionitrilo como eluyente a 20 ㅇ. . Aunque el perfil cromatográfico obtenido usando propionitrilo fue similar al obtenido usando acetona/acetonitrilo, se encontraron diferencias en los triacilgliceroles minoritarios que contribuyen a cada pico cromatográfico. La precisión del método fue buena.

PALABRAS-CLAVE: Aceite oliva - CLAE - NCE - Parejas críticas - Propionitrilo - Triacilgliceroles.

\section{SUMMARY}

Improved method for the determination of triacylglycerols in olive oils by high performance liquid chromatography.

The analysis of triacylglycerols has great importance as quality control and origin determination aid in olive oils analytical methodologies. New improvements in the analysis of triacylglycerols by high-performance liquid chromatography in olive oils are developed in order to increase the separation between LLL/OLLn and OLL/OOLn critical pairs used for detection of seed oils in olive oils. Elution with acetone/acetonitrile (55:45) using gradient temperature and isothermal elution with propionitrile were investigated, in comparison with the European Union official method. The best resolution was achieved using propionitrile at $20^{\circ} \mathrm{C}$. Although the HPLC profile was similar using propionitrile and acetone/acetonitrile, differences in minor triacylglycerols contributing to each HPLC peak were encountered. The precision of the method was good.

KEY-WORDS: Critical pairs - ECN - HPLC - Olive oil Propionitrile -Triacylglycerols.

\section{INTRODUCTION}

The analysis of edible oils by their triacylglycerol (TAG) content has recently assumed a great importance as far as quality control and possible origin determination (Graciani-Constante 1988a); (Graciani-Constante 1988b); (Aitzetmuller 1993). Thus, the percentage of trilinolein (LLL) was adopted as criterion to detect the presence of seed oils in olive oils (EEC 2568/91). Lately, it was substituted by a new parameter: differences between experimental and theoretical values of triacylglycerols with equivalent carbon number equal to 42 ( $\Delta \mathrm{ECN} 42$ ) (EEC 2472/97). In these official methods, the oil is previously purified by passing through a silica-gel column and then the TAG composition determined by isocratic non-aqueous reversed-phase high-performance liquid chromatography (HPLC) with refractive index (RI) detector using acetone/acetonitrile (1:1) as mobile phase (EEC 2568/91). The TAGs are separated according to their equivalent carbon number (ECN), which is defined by the formula: $\mathrm{ECN}=\mathrm{CN}-2 \mathrm{n}$, where $\mathrm{CN}$ is the acyl carbon number and $n$ the number of double bonds of fatty acids constituting the triacylglycerols (Firestone 1994). The $\triangle \mathrm{ECN} 42$ determination allows the detection of seed oils at detection level of $1-3 \%$, but in the case of hazelnut oil the detection level increases up to $20 \%$, because the TAG composition of the hazelnut oil is similar to that of olive oil.

Recently a new method based in the comparison of mathematical algorithms with those included in a database built with genuine olive oils has been proposed (Cert and Moreda 2000). These algorithms are constituted by parameters obtained from the theoretical TAG composition calculated from the fatty acid composition and the experimental TAG composition determined by HPLC. For a successful application of this method, an accurate determination of the TAGs, in particular LLL and OLLn, is necessary. Nevertheleess, the chromatographic resolution achieved with the official analytical method is poor, and therefore, improvements to the TAG analysis by HPLC should be introduced.

Triacylglycerols are effectively separated by HPLC on reversed-phase (RP) columns, containing silica with chemically bonded to octadecyl groups (RP-18) as stationary phase. Using nitriles as mobile phase, separation of TAGs occurs according to the chain length and degree of unsaturation of the fatty acids in the glycerol moiety (Schulte 1981). The 
nitrile most commonly used is acetonitrile with an organic modifier to improve the solubility of TAG bringing about changes in mobile phase polarity, increasing peak selectivity, retention times and selectivity of pairs of groups of TAG with the same ECN. Although, many organic modifiers have been used, the most commonly employed is acetone in different proportions. In the official methods, acetone/acetonitrile (1:1) is used as mobile phase (IUPAC 1987); (EEC 2472/97). However, these methodologies yield only relatively satisfactory separations for critical pairs LLL/OLLn and OLL/OOLn. Using propionitrile, Fiebig 1985, achieved better separations on long HPLC columns $(500 \times 4$ $\mathrm{mm}, 5 \mathrm{~m}$ particle size) at $27.5^{\circ} \mathrm{C}$, and Ollivier et al. 1999 also obtained good separations using shorter columns ( $250 \times 4 \mathrm{~mm}, 4 \mathrm{~m}$ particle size) at $24{ }^{\circ} \mathrm{C}$ and linear flow gradient. Mixtures of acetonitrile with tetrahydrofuran, dichloromethane and chloroform in different proportions (Graciani-Constante and Delgado-Noriega 1987), (Bouteiller and Maurin 1991) have been also assayed.

Most analysis of TAG has been done with the column at ambient temperature. However, changes in column temperature resulted in changes in chromatographic resolution, showing that higher column temperature decreased retention times (Fiebig 1985) and selectivity for the TAG, especially for those critical pairs. Although, lower temperatures results in better separations of the TAG, the election of the temperature analysis represent a compromise to ensure good solubility of the saturated TAG, good selectivity of the critical pairs with the same ECN and shorter run time (Frede 1986).

In this work, several variables affecting to TAG determination in olive oils are changed, in order to achieve a better separation of critical pairs than in the official methods. These changes are size of stationary phase particle, column temperature and nature of mobile phase. The triacylglycerol contributing to each HPLC peak are determined. In addition, the application of solid phase extraction (SPE) to the oil purification (Cert et al. 1996) is proposed.

\section{MATERIALS AND METHODS}

\subsection{Materials}

All reagents were of analytical grade, except acetone, acetonitrile and propionitrile, which were of super purity grade from Romil (Cambridge, United Kingdom).

Silica gel cartridges of $1 \mathrm{~g}(6 \mathrm{ml})$ for solid phase extraction were purchased from Waters (Massachusetts, USA).
Reference triacylglycerols (SSS, PPP, PoPoPo and $\mathrm{OOO}$ ) were supplied by Sigma-Aldrich (St. Louis, MO, USA).

For the assays, virgin olive oils from different varietal origins were chosen in order to have a wide range of fatty acid composition.

\subsection{Oil purification}

The oil samples were purified by passing the oil through silica SPE. Silica SPE column was placed in a vacuum elution apparatus and washed under vacuum with $6 \mathrm{ml}$ of hexane. The vacuum was released to prevent the dryness of the column and then a solution of the oil $(0.12 \mathrm{~g})$ in $0.5 \mathrm{ml}$ of hexane was charged into the column. The solution was pulled through and then eluted with $10 \mathrm{ml}$ of hexane-diethylether $(87: 13 \mathrm{v} / \mathrm{v})$ under vacuum. The eluted solvents were homogenised and evaporated to dryness in a rotary evaporator under reduced pressure at room temperature. The residue was dissolved, in $2 \mathrm{ml}$ of acetone for triacylglycerol (TAG) analysis.

\subsection{HPLC analysis of triacyiglycerols}

A $10 \mu \mathrm{l}$ aliquot of the purified oil solution in acetone (5\%) was injected onto the HPLC system using an autosampler Beckman Gold 508 (Beckman-Coulter, Fullerton, CA, U.S.A.). The analyses were done on a Lichrosphere 100 RP-18 $(4 \mathrm{~m})$ column ( $25 \mathrm{~cm} \times 4 \mathrm{~mm}$ I.D.) using a Beckman Gold 126 pumping unit (Beckman-Coulter, Fullerton, CA, U.S.A.), refractive index detector Perkin Elmer 200 (Perkin Elmer, Norwalk, CT, USA) and Beckman Mistral peltier column thermostat unit (Beckman-Coulter, Fullerton, CA, U.S.A.).

Method A: EU official method for olive oils (EEC 2568/91; EEC 2472/97). The mobile phase was acetone/acetonitrile $(1: 1)$ at a flow rate to elute trilinolein at $12 \mathrm{~min}$. (1.1 $\mathrm{ml} / \mathrm{min}$ approximately). Oven temperature $30^{\circ} \mathrm{C}$.

Method B: the mobile phase was acetone/ acetonitrile $(55: 45)$ at a flow rate to elute the trilinolein at $13 \mathrm{~min}(1.4 \mathrm{ml} / \mathrm{min}$, approximately). Oven temperature gradient: initial temperature $20^{\circ} \mathrm{C}(30$ min) and then increased up to $35^{\circ} \mathrm{C}$ at $0.5^{\circ} \mathrm{C} / \mathrm{min}$.

Method C: elution with propionitrile at a flow rate to elute the trilinolein at $15.5 \mathrm{~min}(0.6 \mathrm{ml} / \mathrm{min}$, approximately). Oven temperature $20^{\circ} \mathrm{C}$.

\section{RESULTS AND DISCUSSION}

Vegetable oils possess a characteristic and more or less unique pattern of TAG that can be used to determine origin and to detect adulteration. The separation of the TAGs according to their ECN is strongly influenced by the mobile phase composition 
and the column temperature.Using the analytical conditions indicated in the official method for TAG determination in olive oils (method A) (EEC 2568/91; EEC 2472/97), the resolution of most TAG was acceptable, but certain critical pairs remained unresolved, such as, LLL/OLLn in the ECN42, OLL/OOLn, PLL/POLn in the ECN44, and $\mathrm{OOL} / \mathrm{PoOO}$ in the ECN46 groups. Figure 1 shows a HPLC chromatographic profile of a virgin olive oil ("Chamlali" variety) analysed using the three methods. In the profile $A$, it can be seen that the ECN42 triacylglycerols can be accurately determined, but the critical pair LLL/OLLn is not well separated (Cert and Moreda 2000). In order to improve the resolution, acetonitrile/acetone (55:45) as mobile phase was used and the column maintained at sub-ambient temperature $\left(20{ }^{\circ} \mathrm{C}\right)$ using a Peltier oven to thermostat the column. The results showed good separations in the TAG of ECN 42 and 44 but the increase of the retention times because of the low temperatures results in long analysis. To ensure a compromise between the resolution and the run time analysis, the low temperature was maintained until elution of the ECN 44 (30 $\mathrm{min}$ ) and then increased at $0.5^{\circ} \mathrm{C} / \mathrm{min}$ to

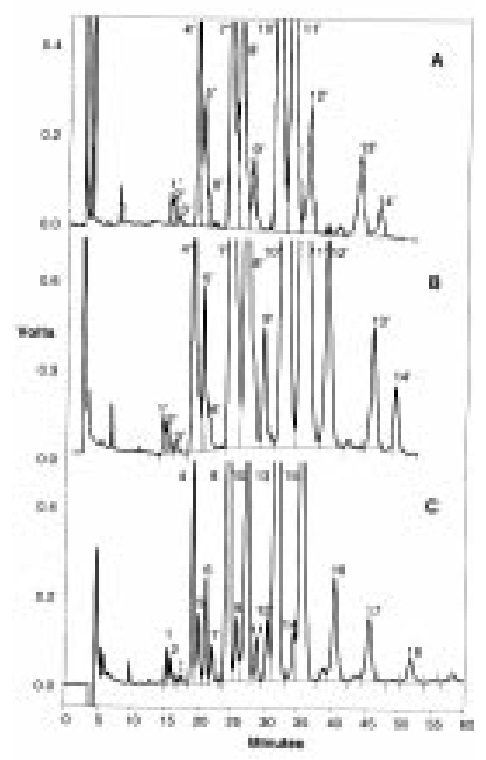

Figure 1

Triacylglycerol HPLC profiles of a virgin olive oil ("Chamlali" variety) using the EU standard analytical method (method A), profile A. Using analytical method B, profile B. Main components of chromatographic peaks for A and B profiles: (1') LLL+PoLL; (2') OLLn+PoOLn; (3') PLLn; (4') OLL+PoOL; (5') OOLn +PLL; (6') POLn+PPoPo; (7') OOL+PoOO; (8') PLO+SLL+ PoOP; (9') PLP+PoPP; (10') OOO; (11') POO+SLL+PPoO; (12') POP+PLS; (13') SOO; (14') POS+SLS. Using method C, (profile C), main components of chromatographic peaks: (1) LLL; (2) OLLn+PoLL; (3) PLLn; (4) OLL; (5) OOLn+PoOL; (6) PLL+PoPoO; (7) POLn+PPoPo+PPoL; (8) OOL+LnPP; (9) PoOO; (10) SLL+PLO; (11) PoOP+SPoL+SOLn+SPoPo; (12) PLP; (13) OOO+PoPP;

(14) SOL; (15) POO; (16) POP; (17) SOO; (18) POS+SLS. reach $35^{\circ} \mathrm{C}$ at the end of the analysis (60 minutes) (Figure 1, profile B). The obtained separation of the critical pairs was better than the standard method in the area of the ECN42 and ECN44. Although, this method yield better results, the improvements were not enough to obtain good separations between peaks. Therefore, seeking new improvements in the analysis of TAGs was necessary.

The steps were directed toward the use of new eluting solvents. Several solvents were tested and propionitrile resulted in the most suitable. Although its toxicity is higher than the acetonitrile, the use of a single elution solvent and an autosampler decreases dramatically the risk of vapour inhalation. This method (method C) yielded an HPLC chromatogram of virgin olive oil ("Chamlali" variety) in which the resolution of the critical pairs is almost complete (Figure 1, profile C). Figure 2 shows the different HPLC profiles obtained from an oil with low linoleic content ("Picual variety"), in which it can be seen that the resolution and quantitation of LLL using method $C$ (Figure 2, profile $C$ ) is much better tan in the other methods; Figure 2, profiles $A$ and $B$. These results encourage its use and therefore, it was worthwhile to perform a complete study of the assignment of the

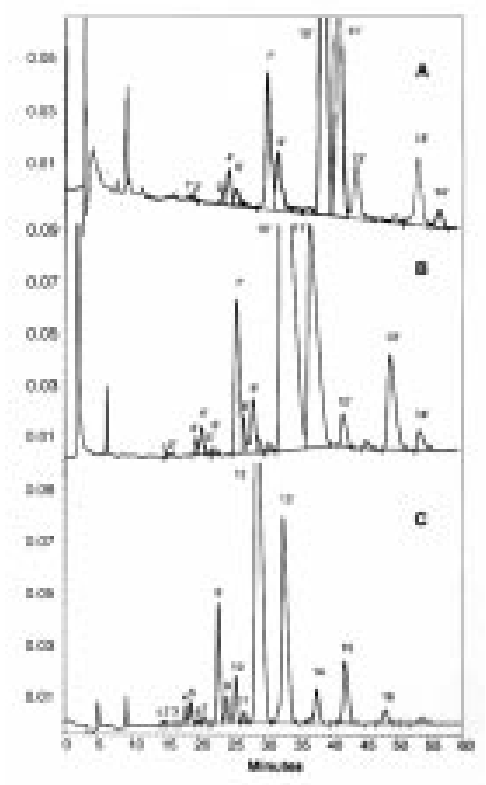

Figure 2

Triacylglycerol HPLC profiles of a virgin olive oil ("Picual" variety) using the EU standard analytical method (method A), profile $A$. Using analytical method B, profile B. Main components of chromatographic peaks for A and B profiles: (1') LLL+PoLL; (2')

OLLn+PoOLn; (3') PLLn; (4') OLL+PoOL; (5') OOLn +PLL; (6') POLn+PPoPo; (7') OOL+PoOO; (8') PLO+SLL+PoOP; (9') PLP+POPP; (10') OOO; (11') POO+SLL+PPoO; (12') POP+PLS;

(13') SOO; (14') POS+SLS. Using method C, (profile C), main components of chromatographic peaks: (1) LLL; (2) OLLn+PoLL; (3) PLLn; (4) OLL; (5) OOLn+PoOL; (6) PLL+PoPoO; (7)

POLn+PPoPo+PPoL; (8) OOL+LnPP; (9) PoOO; (10) SLL+PLO; (11) PoOP+SPoL+SOLn+SPoPo; (12) PLP; (13) OOO+PoPP;

(14) SOL; (15) POO; (16) POP; (17) SOO; (18) POS+SLS. 


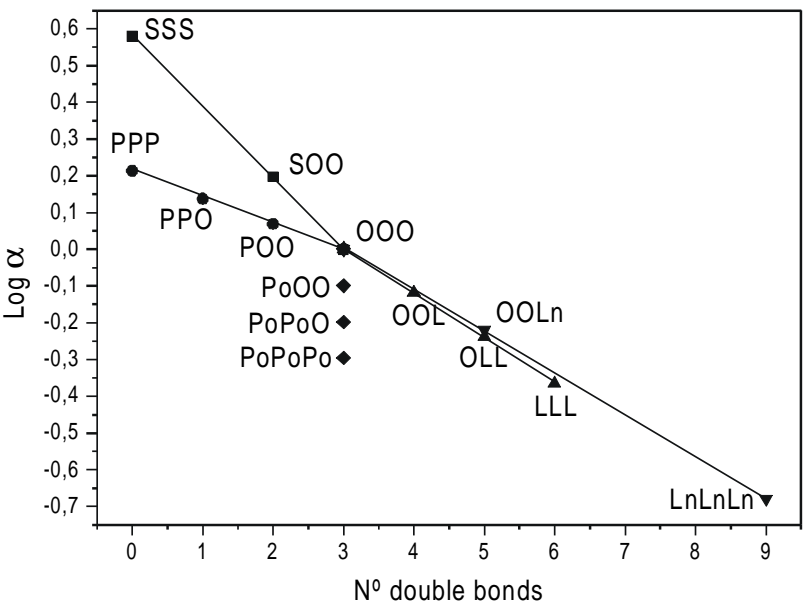

Figure 3

Plot of the log a versus number of double bonds for the series $\mathrm{S}-\mathrm{O}, \mathrm{P}-\mathrm{O}, \mathrm{O}-\mathrm{L}, \mathrm{O}-\mathrm{Ln}$ and $\mathrm{O}$ - Po using method C.

peaks and precision of the method. The use of propionitrile instead of acetone/acetonitrile, reduces dramatically the baseline drift due to the volatility of the solvent and, therefore, better quantitations can be obtained.
The first step was towards the assignment of the corresponding peaks. Elution order is determined by calculating equivalent carbon number, ECN, often defined as $C N-2 n$. To calculate ECN more accurately, a plot of log versus $n$ was depicted for various series ( $\mathrm{S}-\mathrm{O}, \mathrm{P}-\mathrm{O}, \mathrm{O}-\mathrm{L}, \mathrm{O}-\mathrm{Ln}$ and $\mathrm{O}-$ Po series) (Figure 3), being $\alpha=\frac{R T_{i}-R T_{s}}{R T_{000}-R T_{s}} \quad\left(R T_{i}\right.$ is the retention time of the TAG, $R T_{s}$ the retention time of the solvent and $R T_{000}$ the retention time of the triolein). In this plot, it can be seen that the successive replacement of the fatty acid moiety having the same $\mathrm{CN}$ results in a change in the log. Under these chromatographic conditions conditions, ECN approximates: $E C N=C N-\left(3.15 \times n_{0}\right)-\left(2.90 \times n_{P O}\right)$ $\left(2.34 n_{L N}\right)$ where $n_{O}, n_{P o}, n_{L}$ and $n_{\llcorner n}$ are the number of double bonds of oleic, palmitoleic, linoleic and linolenic acids respectively, and the coefficients are calculated from reference triacylglycerols (Firestone 1994).

Using the above equation, it was possible to assign the different peaks in HPLC analysis with propionitrile as mobile phase (Figures 1 and 2, profiles $\mathrm{C}$ ). It can be seen that the triacylglycerols contributing to the HPLC peaks are different using acetone/acetonitrile and propionitrile elution.

Table I

Repeatability data of the determination of virgin olive oil TAGs by HPLC using propionitrile as eluent

\begin{tabular}{|c|c|c|c|c|c|c|c|c|c|c|c|c|}
\hline \multirow[b]{2}{*}{ ECN } & \multirow[b]{2}{*}{$\begin{array}{l}\text { HPLC } \\
\text { peaks }\end{array}$} & \multirow[b]{2}{*}{ TAGs } & \multicolumn{2}{|c|}{ Sample 1} & \multicolumn{2}{|c|}{ Sample 2} & \multicolumn{2}{|c|}{ Sample 3} & \multicolumn{2}{|c|}{ Sample 4} & \multicolumn{2}{|c|}{ Sample 5} \\
\hline & & & 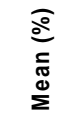 & $\begin{array}{l}\widehat{o} \\
\vdots \\
0 \\
0\end{array}$ & $\begin{array}{l}\text { ळ } \\
\text { ฮ } \\
\text { ฮ } \\
\sum\end{array}$ & 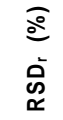 & 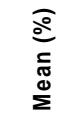 & $\begin{array}{l}\widehat{o} \\
\stackrel{0}{2} \\
\check{x}\end{array}$ & $\begin{array}{l}\text { ळ } \\
\text { ฮ } \\
\text { ฮ }\end{array}$ & $\begin{array}{l}\text { ळ } \\
\text { के } \\
\simeq 1\end{array}$ & $\begin{array}{l}\text { ఏ } \\
\text { こ } \\
\text { ळ } \\
\sum\end{array}$ & $\begin{array}{l}\widehat{o} \\
\stackrel{0}{2} \\
\mathscr{2}\end{array}$ \\
\hline \multirow{3}{*}{42} & 1 & LLL & 0.020 & 7.23 & 0.066 & 5.18 & 0.095 & 4.10 & 0.113 & 0.95 & 0.34 & 1.05 \\
\hline & 2 & $\begin{array}{l}\text { OLLn+ } \\
\text { PoLL }\end{array}$ & 0.085 & 7.44 & 0.24 & 1.78 & 0.26 & 2.25 & 0.35 & 2.02 & 0.50 & 2.83 \\
\hline & 3 & PLLn & 0.023 & 15.74 & 0.039 & 5.51 & 0.057 & 5.62 & 0.082 & 4.35 & 0.12 & 6.15 \\
\hline \multirow{4}{*}{44} & 4 & OLL & 0.47 & 1.52 & 1.53 & 0.42 & 2.62 & 0.98 & 3.35 & 1.05 & 4.37 & 1.13 \\
\hline & 5 & $\begin{array}{c}\text { OOLn+ } \\
\text { PoOL }\end{array}$ & 1.07 & 2.01 & 1.54 & 0.46 & 1.61 & 0.71 & 1.72 & 1.07 & 1.77 & 2.40 \\
\hline & 6 & $\begin{array}{c}\text { PLL+ } \\
\text { PoPoO }\end{array}$ & 0.11 & 12.86 & 0.24 & 4.37 & 0.65 & 1.32 & 1.35 & 0.73 & 2.28 & 1.24 \\
\hline & 7 & $\begin{array}{c}\text { POLn+ } \\
\text { PPoPo+ } \\
\text { PPoL }\end{array}$ & 0.42 & 5.11 & 0.49 & 2.89 & 0.55 & 2.01 & 0.85 & 1.83 & 1.09 & 1.96 \\
\hline \multirow{4}{*}{46} & 8 & $\begin{array}{l}\text { OOL+ } \\
\text { LnPP }\end{array}$ & 6.72 & 0.63 & 8.79 & 0.31 & 11.21 & 0.42 & 13.25 & 0.33 & 15.24 & 0.23 \\
\hline & 9 & $\mathrm{PoOO}$ & 1.24 & 2.86 & 1.49 & 0.95 & 1.63 & 0.85 & 2.12 & 0.45 & 2.52 & 0.56 \\
\hline & 10 & $\begin{array}{l}\text { SLL+ } \\
\text { PLO }\end{array}$ & 2.70 & 0.65 & 4.05 & 0.70 & 6.02 & 0.65 & 9.86 & 0.53 & 11.53 & 0.31 \\
\hline & 11 & $\begin{array}{l}\text { PoOP+ } \\
\text { SPOL+ } \\
\text { SOLn+ } \\
\text { SPOPO }\end{array}$ & 0.64 & 4.42 & 0.69 & 3.02 & 0.79 & 1.23 & 1.53 & 0.89 & 1.70 & 1.66 \\
\hline \multirow[t]{3}{*}{48} & $12+13$ & $\begin{array}{l}\text { OOO+ } \\
\text { PLP+ } \\
\text { PoPP }\end{array}$ & 49.60 & 0.07 & 48.15 & 0.06 & 42.93 & 0.06 & 33.25 & 0.10 & 24.16 & 0.06 \\
\hline & 14 & SOL & 0.82 & 1.72 & 0.92 & 1.56 & 1.05 & 1.32 & 1.25 & 1.05 & 1.60 & 1.77 \\
\hline & 15 & $\mathrm{POO}$ & 22.75 & 0.25 & 21.80 & 0.20 & 21.05 & 0.30 & 20.36 & 0.35 & 20.17 & 0.14 \\
\hline \multirow{3}{*}{50} & 16 & POP & 3.05 & 0.46 & 4.56 & 0.42 & 4.98 & 0.52 & 5.26 & 0.41 & 5.57 & 0.38 \\
\hline & 17 & SOO & 6.87 & 0.21 & 5.56 & 0.33 & 4.86 & 0.43 & 4.12 & 0.72 & 3.09 & 0.69 \\
\hline & 18 & $\begin{array}{l}\text { POS+ } \\
\text { SLS }\end{array}$ & 1.73 & 1.23 & 1.65 & 1.10 & 1.54 & 0.99 & 1.49 & 1.10 & 1.41 & 1.00 \\
\hline
\end{tabular}

$n=3$ replicates

$\begin{aligned} & n=3 \text { replicates } \\ & R S D\end{aligned}=$ Relative $S$ tandard Deviations of the repeatability 
In order to evaluate the repeatability of the determination of the TAGs by HPLC using propionitrile as eluent, analysis of virgin olive oils having different fatty acid compositions was performed 3 times. The results obtained (Table I) indicate that the relative standard deviation of the method is good.

\section{ACKNOWLEDGEMENTS}

The authors wish to thank the European Commission for the financial support of the project (GRD1-2000-25011; MEDEO).

\section{REFERENCES}

Aitzetmuller, K. (1993). HPLC of triglycerides (fingerprint method). Fat Sci.Technol. 95, 361-366.

Bouteiller, J.C. and Maurin, R. (1991) Relationship between triacylglycerol structure and retention times in HPLC. Rev.Fran.Corps Gras 9/10, 297-304.

Cert, A. and Moreda, W. (2000). Algorithms for the detection of hazelnut oil in olive oil. Grasas Aceites 51, 143-149.

Cert, A., Moreda, W., León-Camacho, M. and Pérez-Camino, M.C. (1996). Determinación de la absorción de luz ultravioleta a $232 \mathrm{~nm}$, hidrocarburos esteroideos, esteres metílicos de ácidos grasos y triglicéridos en aceites de oliva. Resultados de un estudio colaborativo. Grasas Aceites 47, 401-410.

Commision Regulation (EEC) No. 2568/91 of July 1991. On the characteristics of olive and olive pomace oils and on their analytical methods. Off.J.Eur.Commun. L248, 29-32.

Commission Regulation (EC) No 2472/97 of 11 December 1997 amending Regulation (EEC) No 2568/91 on the characteristics of olive oil and olive-residue oil and on their methods of analysis. Off.J.Eur.Commun. L341, 25-39.

Fiebig, H.J. (1985). HPLC separation of triglycerides. Fett.Seifen Anstrich. 87, 53-57.

Firestone, D. (1994). Liquid chromatographic method for determination of triglycerides in vegetable oils in terms of their partition numbers: summary of collaborative study. J.AOAC Int. 77, 954-957.

Frede, E. (1986). Improved HPLC of triglicerides by special tempering procedures. Chromatographia 21, 29-36.

Graciani-Constante, E. (1988a). Characterization of Spanish virgin olive oil. IV. Comparison with other oils and fats according to their compositions in triacylglycerols. Grasas Aceites 39, 163-173.

Graciani-Constante, E. (1988b). Charcterization of Spanish virgin olive oil. III. Possibility of characterization by olive variety or oleicole zone according to its triacylglycerols content. Grasas Aceites 39, 105-110.

Graciani-Constante, E. and Delgado-Noriega, M.L. (1987). Characterization of spanish virgin olive oil. I. Study of the variables which take part in its triacylglycerols separation by HPLC. Grasas Aceites 38, 286-293.

IUPAC (1987). Standard Method 2324. Determination of composition of triacylglycerols in vegetable oils in terms of their partition number by HPLC, in Standard Methods for the Analysis of Oils, Fats and Derivatives. $7^{\text {th }}$ ed., Oxford, Blackwell.

Schulte, E. (1981). Separation of triglycerides according to chain length and degree of saturation by HPLC. Fett.Seifen Anstrich. 83, 289-291. 